\title{
Diversity of Seed-Borne Mycoflora in Relation to Different Chickpea Varieties in Uttar Pradesh, India
}

\author{
Ankita Tripathi ${ }^{1 *}$, Alok K. Srivastava ${ }^{1}$, Alvina Farooqui ${ }^{2}$, Ajita Singh $^{3}$, \\ ${\text { Dinesh } \text { Singh }^{4} \text { and Vainkteshvar K. Tripathi }}^{5}$
}

\author{
${ }^{1}$ ICAR-National Bureau of Agriculturally Important Microorganisms, \\ Maunath Bhanjan 275101, India \\ ${ }^{2}$ Integral University, Dasauli, Kursi Road, Lucknow 226026, India \\ ${ }^{3}$ Sardar Vallabhbhai Patel University of Agriculture and Technology 2501 10, India \\ ${ }^{4}$ ICAR- Indian Institute of Sugarcane Research, Lucknow 226002, India \\ ${ }^{5}$ ICAR-Central Institute for Subtropical Horticulture, Lucknow UP, 226101, India
}

*Corresponding author

\section{A B S T R A C T}

\section{Keywords}

Chickpea, Variety, Seed, Diseases, Mycoflora, Diversity, Fusarium oxysporum f. sp. cicero and Aflatoxins

\section{Article Info}

Accepted: 17 September 2019 Available Online: 10 October 2019
Chickpea (Cicer arietinum.) is grown extensively in India as an important legume crops. A quality seed is required to increase the production of chickpea qualitatively and quantitatively. Hence it is imperative that seeds must be tested for seed-borne mycoflora (seed-health), before they are sown in the field. In the context, a study was conducted to work out the diversity of seed-borne mycoflora in relation to different chickpea varieties. Seeds of ten varieties of chickpea were subjected to Standard Purity Work Board technique and Standard Blotter Paper Method technique (ISTA 2007) for the detection and isolation of seed-borne mycoflora. After incubation of seeds, fungi developed on each seed were examined. Standard Purity Work Board technique results revealed that among the different varieties tested, variety KGD 11 was rated as resistant to seed-born mycoflora with 370 healthy seeds, 11 deformed seeds, 10 wrinkled seeds, 30 discoloured seeds and 13 fruiting body seeds followed by Awarodhi with 364 healthy seeds, 25 deformed seeds, 18 wrinkled seeds, 36 discoloured seeds and 21 fruiting body seeds. Variety JG 315 and PUSA 362 was rated as susceptible in respect to physical seed abnormalities with 169 healthy seeds, 58 deformed seeds, 107 wrinkled seeds, 231 discoloured seeds, 72 fruiting body seeds and 203 healthy seeds, 63 deformed seeds, 85 wrinkled seeds, 197 discoloured seeds, 68 fruiting body seeds, respectively. It was evident with the experimentation that chickpea wilt disease causing pathogen Fusarium oxysporum which is the most yield limiting factors in chickpea was found associated with the seeds of all the widely adopted chickpea varieties viz., L 550, BG 3004, Pragati, BGD 72, JG 11, RSG 807, PUSA 362 and JG 315 except two varieties namely KGD 11 and Awarodhi. Variety KGD 11 was found more tolerant for the per cent infection of seed that is $10.00 \%$ under pre-treated (PT) condition and $21.50 \%$ under untreated (UT) condition with $99 \%$ germination (UT), $100 \%$ germination (PT) and five seed associated fungi viz.,Alternaria alternata, Curvularia lunata, Fusarium semitectum, Aspergillus niger and Rhizopus arrhizus. 


\section{Introduction}

Pulses play an important role in Indian agriculture to the maintaining soil fertility and supplying protein to the large vegetarian population of the country. Nearly 11,000 species of legumes are known and many are of importance as industrial, medicinal of food plants. Considering the nutritional, agronomical and industrial value of pulses and yield of legumes the present study is aimed to work out the diversity of seed-borne mycoflora in relation to different chickpea varieties in Uttar Pradesh.

Chickpea (Cicer arietinum L.) commonly known as 'gram' is the most important legume grown in India and grown over $6.66 \mathrm{~m}$ ha of land (Kochhar, 2009). It has been found to be attacked by 172 pathogens including 67 species of fungi (Nene et al., 1996). Chickpea suffers from a large number of fungal diseases namely Ascochyta blight (Ascochyta rabiei), Fusarium wilt ( $F$. oxysporum f. sp. ciceri), dry root rot (Rhizoctonia bataticola) Alternaria blight (Alternaria alternata), Colletotrichum blight (Colletotrichum dematium), Stemphylium blight (Stemphylium sarciniforme), powdery mildew (Leveillula taurica), Sclerotinia stem rot (Sclerotinia sclerotiorum), wet root rot (Rhizoctonia solani) and foot rot (Operculella padwickii) (Singh and Sharma, 2005; Dubey et al., 2007).

Out of many fungal pathogens, some of which are seed transmitted, often reduce the germination ability or kill the infected plants or substantially reduce the production potential of its genetic levels. Some of these fungi produce afla-toxins which damage the liver and induce carcinogenic, mutagenic and teratogenesis (Pereyra et al., 2008). Therefore, control of seed-borne fungi is extremely important. Therefore, the study was undertaken to investigate diversity of incidence of seed-borne fungi associated with chickpea seeds to protect these seeds from fungal diseases.

\section{Materials and Methods}

The study was conducted to work out the distribution of pathogenic mycoflora associated with the seed of five most widely cultivated varieties of chickpea in Directorate of Seed Research, Mau and National Bureau of Agriculturally Important Microorganisms, Mau. The material used and methods followed are as under. Seed samples of nine most widely cultivate $\mathrm{d}$ varieties of chickpea viz., $\mathrm{L}$ 550, BG 3004, KGD11, Pragati, Awarodhi, BGD 72, JG 11, RSG 807 and PUSA 362 and one susceptible standard check for Fusarium oxysporum f. sp. ciceri namely JG 315 were collected from AICRP on National Seed Project (Crops) of Directorate of Seed Research, Mau in sterilized polythene bags. Composite sample of each varieties were prepared by following the method described by Paul and Neergard (1977). The collected seeds were preserved at $05 \mathrm{C}$ to avoided further contamination and for subsequent experimentation.

\section{Standard purity work board technique}

All the samples were subjected to the visual inspection by naked eye, under stereoscopic binocular microscope added with cool-light condition and by modified purity work board. Seeds with black point disease can be easily differentiated by the pronounced appearance of brown to dark brown or blackish discoloured areas. Symptoms on the seeds, having elliptical to oblong lesionswith lighter in center represent the presence of Bipolaris sorokiniana. Curvularia lunata resulted brown coloration of seed coats. Alternaria alternata was identified by the presence of dark brown and long conidial chain on incubated seed surface. 


\section{Standard blotter paper method technique}

The stored seed samples of chickpea were subjected to Standard Blotter Paper Method (ISTA, 1996), a seed associated mycoflora detection techniques for detection of seedborne pathogen. Two hundred seeds of all the samples were used in one replication under CRD of Standard Blotter Paper Method, each for un-treated (UT) seeds and pre-treated (PT) seeds after treatment with $0.1 \%$ mercuric chloride $\left(\mathrm{HgCl}_{2}\right)$ solution. The seeds were placed in petridishes containing three layers of moistened blotter with defined quantity of streptopenicillin to avoid growth of bacteria as contamination. The petridishes were incubated at $24 \pm 1{ }^{\circ} \mathrm{C}$ under 24 hours alternating cycle of light and darkness for 7 days in the incubation chamber. The single spore isolation techniques were followed to purify the culture for further studies.

Potato Dextrose Agar (PDA) and CzapakDox Agar (CDA), and Spezieller Nahrst of farmer Agar (SNA) medium as per described by Nirenberg 1976 were use to maintain the mycoflora. The sterilized media was poured into $9 \mathrm{~cm}$ diameter, petridishes. Fusarium spp. were placed in the centre of the plates and was incubated at $25 \pm 1{ }^{0} \mathrm{C}$. Sporulating cultures were obtained by placing autoclaved filter paper strip at the periphery of actively growing colonies. The isolated strains were identified after growth on CzapakDox Agar and Potato Dextrose Agar (Lacaz, et al., 1991). Identification keys developed byBaijal and Mehrotra, 1980; Bissett, 1991; Domsch, et al., 1993; Pitt, 1998; Hammil, 1970; Raper and Fennell, 1975; Refai, 1969; Samuels et al., 1998; and Sutton, 1980were used to identify the seed-borne mycoflora.

\section{Results and Discussion}

The experiments were conducted to work out the diversity/load of seed-borne mycoflora on commercially cultivated chickpea seeds of ten different varieties. Seed samples of all the commercially cultivated varieties of chickpea were collected in sterilized polythene bags and stored under low temperature. Further the samples were analyzed for the associated mycoflora by employing the standard techniques with pre-treated and untreated seeds. Microscopic characteristics including colour, texture, appearance and diameter of the fungal colonies were compared for the identification of mycoflora.

\section{Detection of seed health by Standard Purity Work Board Technique}

The commercially cultivated chickpea seed samples of all the varieties were analyzed on standard purity work board under dry conditions. Healthy and diseased seeds were sorted out by visual examination. Diseased seeds were categorized as deformed, shrivelled, deshaped and discoloured seed. All the samples were examined for the associated mycoflora in which the dry seeds were subjected to the visual inspection by necked eye, under stereoscopic binocular microscope added with cool-light condition and by modified purity work board. Seeds with wilt disease can be easily differentiated by the pronounced appearance of profuse mycelial growth of the Fusarium oxysporum f. sp. Cicero fungus on seed surface and pink discolourations. Seeds infected with Anthracnose disease of chickpea produces symptoms of Colletotrichum necrotic lesions on seed coat and also shrivelled in shape, resulting significant dockage on seed. Chickpea Ascochyta blight infected seeds exhibited black, brown or grey necrotic lesions on the seed-coat due to presence of Ascochyta rabiei fungus. Graymold disease of chickpea caused by Botrytis cinerea may be confirmed in the presence of gray/brown lesions on seeds, and are often covered with a gray mass of fungal hyphae and spores. The 
size of infected seeds was also reduced up to the significant level and badly discoloured. The associations of above mentioned mycoflora were finally confirmed after plating of seeds (stored sample) by using standard blotter method. The results of other examinations by using Standard Purity Work Board Technique (Table 1), revealed that maximum fruiting body seed was recorded 96.00 seeds with the variety Pragati followed by 72.00 seeds (JG 315), 68 seeds (PUSA 362 ) and 28 seeds with variety BG 3004. The minimum fruiting body seed was recorded 13 seeds with the variety KGD 11. Two more varieties namely RSG 807 and L 550 were found statistically at par in respect to minimum fruiting body seeds as 14 seeds and 17 seeds, respectively.

The difference between maximum and minimum fruiting body seed was statistical significant for determining the resistant and susceptible variety on the basis of fruiting body seeds. The minimum discoloured seed was recorded 30 seeds with the two variety KGD 11 and statistically at par with the variety Awarodhi with 36 seeds and variety $L$ 550 with 39 seeds. Two more variety JG 11 (42 seeds) and BGD 72 (49 seeds) also recorded less than 50 discoloured seeds and statistically at par with the variety KGD 11 . Whereas maximum discoloured seed was observed 231 seeds with the variety JG 315 followed by 197 seeds with the variety PUSA 362 and 187 seeds with the variety Pragati. The difference between maximum and minimum discoloured seeds was also found statistical significant for determining the resistant and susceptible variety on the basis of discoloured seeds. The maximum wrinkled seed was recorded 107 seeds with the variety JG 315 followed by 85 seeds (PUSE 362) and 81 seeds (Pragati). Whereas the minimum wrinkled seed was recorded 10 seeds with the variety KGD 11 followed by 11 seeds (L 550) and 13 seeds (BGD 72). The maximum and minimum differences of wrinkled seed in the studied varieties were also statistically significant to each other. In case of deformed seed, 63 seeds were found as maximum deformed seeds with the variety PUSA 362 followed by 58 seeds (JG 315) and 56 seeds (Pragati) and statistically non-significant with the minimum deformed seed of 09 with the variety RSG 807 followed by 11 seeds (KGD 11) and 14 seeds (L 550).

The maximum healthy seeds of 370 was recorded with the variety KGD 11 followed by 364 seeds (Awarodhi) and 361 seeds (L 550) and statistically significant with the minimum of 169 healthy seeds with the variety JG 315 followed by PUSA 362 (203 seeds) and Pragati (213 seeds).Overall under the dry seed examination (a non-injuring seed health test) method of detection, variety KGD 11 was rated as resistant to seed-born mycoflora with 370 healthy seeds, 11 deformed seeds, 10 wrinkled seeds, 30 discoloured seeds and 13 fruiting body seeds followed by Awarodhi with 364 healthy seeds, 25 deformed seeds, 18 wrinkled seeds, 36 discoloured seeds and 21 fruiting body seeds. Variety JG 315 and PUSA 362 was rated as susceptible in respect to physical seed abnormalities with 169 healthy seeds, 58 deformed seeds, 107 wrinkled seeds, 231 discoloured seeds, 72 fruiting body seeds and 203 healthy seeds, 63 deformed seeds, 85 wrinkled seeds, 197 discoloured seeds, 68 fruiting body seeds, respectively.

\section{Detection of seed health by standard blotter paper method technique}

Among the ten most widely cultivated varieties of chickpea seeds tested, the variety KGD 11 was found more tolerant for the per cent infection of seed that is $10.00 \%$ under pre-treated (PT) condition and $21.50 \%$ under untreated (UT) condition with $99 \%$ germination (UT), $100 \%$ germination (PT) andfive seed associated fungi viz., Alternaria 
alternata, Curvularia lunata, Fusarium semitectum, Aspergillus niger and Rhizopus arrhizus (Table 2). Except susceptible standard check for Fusarium oxysporumf. sp. ciceri variety JG 315, variety Pragati was found more susceptible for the per cent infection of seeds in both PT (42.00\% seeds) and UT (55.60\% seeds) condition with $99 \%$ germination (UT), $100 \%$ germination (PT) and 12 seed associated fungi viz., Alternaria alternata, Botrytis cinerea, Colletotrichum truncatum, Ascochyta rabiei, Fusarium oxysporum, F. semitectum, Aspergillusflavus, A. niger, A. fumigatus, Mucorspecies, Penicillium notatum, and Rhizopus arrhizus. The variety Awarodhi and JG 11 was also rated as tolerant for the per cent infection of seed. Awarodhi exhibited $11.25 \%$ (PT)and $24.74 \%$ seed infection with $93.00 \%$ germination (UT), $99.00 \%$ germination (PT) and six seed associated fungi viz., Alternaria alternata, Curvularia lunata, Fusarium semitectum, Aspergillus niger, A. flavus and Rhizopus arrhizus whereas JG 11 exhibited $14.35 \%(\mathrm{PT})$ and $30.56 \%$ seed infection with $91.00 \%$ germination (UT), $99.00 \%$ germination (PT) and nine seed associated fungi viz., Alternaria alternata, Curvularia lunata, Fusarium oxysporum, Fusarium moniliforme, M. phaseolina, Trichoderma harzanium, A. niger, Mucorspecies, Rhizopus arrhizus. Chickpea Ascochyta blight caused by Ascochyta rabiei was found associated with the seeds of only two varieties namely JG 315 and Pragati whereas one of the most widely spread and destructive diseases of commonly grown cultivars of chickpea wet root rot caused by Rhizoctonia solani pathogen was found associated with the seeds of three varieties namely JG 315, RSG 807 and BGD 72. Macrophomin aphaseolina pathogen causing most devastating disease of charcoal rot and root rot diseases in various economically important crops was found associated with the seeds of two varieties namely JG 315 and RSG 807. It was evident with the experimentation that chickpea wilt disease causing pathogen Fusarium oxysporum which is the most yield limiting factors in chickpea was found associated with the seeds of all the widely adopted chickpea varieties viz., L 550, BG 3004, Pragati, BGD 72, JG 11, RSG 807, PUSA 362 and JG 315 except two varieties namely KGD 11 and Awarodhi.

Maximum of hundred per cent germination under pre-treated condition of seeds was recorded with the variety KGD 11 whereas $99.00 \%$ germination recorded with the three vanities namely BG 3004, Awarodhi and BGD 72. Minimum $52.00 \%$ seed germination under pre-treated condition with the variety JG 315 followed by $58.00 \%$ with the variety PUSA 362.

Un-treated seed condition revealed minimum of $34.00 \%$ germination with the variety JG 315 followed by $48.00 \%$ with the variety PUSA 362 whereas under pre-treated seed condition recorded minimum of $52.00 \%$ germination with the variety JG 315 followed by $58.00 \%$ with the variety PUSA 362 .

Seed-borne diseases are regarded as major limiting factor for chickpea production. Healthy and pathogen free seed is the basic key for disease free crop. Seed-borne infection of fungal pathogens are important not only for its association with the seeds which cause germination failure or causing disease to the newly emerged seedlings or growing plants but also contaminate the soil by establishing its inocula permanently (Hasanet al.,2005). Experimental result showed that saprophytic fungi viz., A. flavus and A. nigerwere predominant among the fungi isolated. Such similar reports have been made by Rasheed $e t$ al., (2004) on groundnut seed. A. flavus and A. nigerwere the predominant storage fungi of groundnut seeds (Mukherjee et al., 1992) and soybean seed (Tariq et al., 2005) (Fig. 1-4). 
Table.1 Standard dry seed examination for detection of FBS, DS, WS, DFS and HS of ten commercially cultivated chickpea varieties

\begin{tabular}{|c|c|c|c|c|c|c|c|}
\hline S.No. & Variety & SE & FBS & DS & WS & DFS & HS \\
\hline $\mathbf{1}$ & L 550 & 400 & 017 & 039 & 011 & 014 & 361 \\
\hline $\mathbf{2}$ & BG 3004 & 400 & 028 & 058 & 021 & 023 & 342 \\
\hline $\mathbf{3}$ & KGD 11 & 400 & 013 & 030 & 010 & 011 & 370 \\
\hline $\mathbf{4}$ & Pragati & 400 & 096 & 187 & 081 & 056 & 213 \\
\hline $\mathbf{5}$ & Awarodhi & 400 & 021 & 036 & 018 & 025 & 364 \\
\hline $\mathbf{6}$ & BGD 72 & 400 & 026 & 049 & 013 & 020 & 351 \\
\hline $\mathbf{7}$ & JG 11 & 400 & 022 & 042 & 020 & 019 & 358 \\
\hline $\mathbf{8}$ & RSG 807 & 400 & 014 & 064 & 016 & 009 & 336 \\
\hline $\mathbf{9}$ & PUSA 362 & 400 & 068 & 197 & 058 & 063 & 203 \\
\hline $\mathbf{1 0}$ & *JG 315 & 400 & 072 & 231 & 107 & 058 & 196 \\
\hline & Mean & & 37.7 & 93.3 & 35.5 & 39.8 & 309.40 \\
\hline & SEm \pm & & 0.71 & 1.70 & 1.16 & 1.21 & 10.3 \\
\hline
\end{tabular}

$S E=$ Seeds examined $; F B S=$ Fruiting body seed DS = Discoloured seed $;$ WS $=$ Wrinkled seed DFS $=$ Deformed seed; $H S=$ Healthy seed

Table.2 Seeds associated mycoflora of commercially cultivated chickpea varieties by Standard Blotter Paper Method before and after surface sterilization

\begin{tabular}{|c|c|c|c|c|c|c|}
\hline \multirow{2}{*}{$\begin{array}{l}\text { S. } \\
\text { N. }\end{array}$} & \multirow[t]{2}{*}{ Varieties } & \multicolumn{2}{|c|}{ Infection (\%) } & \multicolumn{2}{|c|}{ Germination (\%) } & \multirow[t]{2}{*}{ Pathogenic mycoflora associated with seed } \\
\hline & & $\mathbf{U T}$ & PT & UT & PT & \\
\hline 1 & L 550 & 25.75 & 14.75 & 94.00 & 98.00 & $\begin{array}{l}\text { Alternaria alternata, Colletotrichum } \\
\text { truncatum, Helminthosporiumsativum, } \\
\text { Fusarium oxysporum, F. semitectum, } \\
\text { Aspergillus flavus, A. fumigatus, } \\
\text { Mucorspecies and Rhizopus arrhizus.[9] }\end{array}$ \\
\hline 2 & BG 3004 & 25.75 & 15.00 & 91.00 & 99.00 & $\begin{array}{c}\text { Alternariaporri, Curvularia lunata, } \\
\text { Helminthosporiumsativum, Fusarium } \\
\text { oxysporum, F. semitectum, Aspergillus flavus, } \\
\text { A. niger and Mucorspecies.[8] }\end{array}$ \\
\hline 3 & KGD11 & 21.50 & 10.00 & 99.00 & 100 & $\begin{array}{c}\text { Alternaria alternata, Curvularia } \\
\text { lunata,Fusarium semitectum, } \\
\text { Aspergillusnigerand Rhizopus arrhizus. [5] }\end{array}$ \\
\hline 4 & Pragati & 55.60 & 42.00 & 51.00 & 63.00 & $\begin{array}{c}\text { Alternaria alternata, Botrytis cinerea, } \\
\text { Colletotrichum truncatum, Ascochytarabiei, } \\
\text { Fusarium oxysporum, F. semitectum, } \\
\text { Aspergillus flavus, A. niger, A. fumigatus, } \\
\text { Mucorspecies, Penicillium notatum, and } \\
\text { Rhizopus arrhizus. [12] }\end{array}$ \\
\hline 5 & Awarodhi & 24.75 & 11.25 & 93.00 & 99.00 & $\begin{array}{c}\text { Alternaria alternata, Curvularia lunata, } \\
\text { Fusarium semitectum, Aspergillusniger, A. }\end{array}$ \\
\hline
\end{tabular}




\begin{tabular}{|c|c|c|c|c|c|c|}
\hline & & & & & & flavus and Rhizopus arrhizus. [6] \\
\hline 6 & BGD 72 & 38.24 & 23.50 & 89.00 & 90.00 & $\begin{array}{l}\text { Alternaria alternata, Helminthosporium } \\
\text { sativum, Fusarium oxysporum, } F \text {. semitectum, } \\
\text { Colletotrichum truncatum, } R \text {. solani } \\
\text { Penicillium notatum, Rhizopus arrhizus, } \\
\text { Rhizopus sp. and } M \text {. phaseolina. }[10]\end{array}$ \\
\hline 7 & JG 11 & 30.50 & 14.35 & 91.00 & 99.00 & $\begin{array}{l}\text { Alternaria alternata, Curvularia lunata, } \\
\text { Fusarium oxysporum, Fusarium moniliforme, } \\
\text { M. phaseolina, Trichoderma harzanium, A. } \\
\text { niger, Mucor species, Rhizopus arrhizus. [9] }\end{array}$ \\
\hline 8 & RSG 807 & 32.45 & 20.00 & 83.00 & 91.00 & $\begin{array}{l}\text { Alternariaporri, Fusarium oxysporum, } \\
\text { Fusarium moniliforme, } R \text {. solani, } M . \\
\text { phaseolina Penicillium notatumand } \\
\text { Aspergillus flavus. [7] }\end{array}$ \\
\hline 9 & $\begin{array}{c}\text { PUSA } \\
362\end{array}$ & 48.75 & 41.00 & 48.00 & 58.00 & $\begin{array}{c}\text { Alternaria alternata, } \\
\text { Helminthosporiumsativum, Botrytis cinerea, } \\
\text { Colletotrichum truncatum,Fusarium } \\
\text { moniliforme, Fusarium oxysporum, } F . \\
\text { semitectum, Trichoderma harzanium, } \\
\text { Aspergillus flavus, Mucor species and } \\
\text { Rhizopus arrhizus. }[11]\end{array}$ \\
\hline 10 & *JG 315 & 78.50 & 53.00 & 34.00 & 52.00 & $\begin{array}{l}\text { Alternaria alternate, Helminthosporium } \\
\text { sativum, Botrytis cinerea, Colletotrichum } \\
\text { truncatum, Ascochytarabiei, Fusarium } \\
\text { oxysporum, F. semitectum, Fusarium } \\
\text { moniliforme, R. solani, M. phaseolina, } \\
\text { Trichoderma harzanium, Aspergillus flavus, } \\
\text { A. niger, Mucor species, Penicillium notatum, } \\
\text { and Rhizopus arrhizus. [16] }\end{array}$ \\
\hline & Mean & 38.18 & 24.98 & 77.30 & 84.90 & \\
\hline & $\operatorname{SEm} \pm$ & 2.57 & 1.27 & 3.63 & 4.59 & \\
\hline & CD ${ }_{0.01}$ & 7.63 & 3.74 & 10.8 & 13.6 & \\
\hline
\end{tabular}

* JG 315 is used as standard check for $F$. oxysporum f. sp. ciceri

$\mathrm{PT}=$ Pre-treated condition of seed

UT $=$ Un-treated condition of seed 


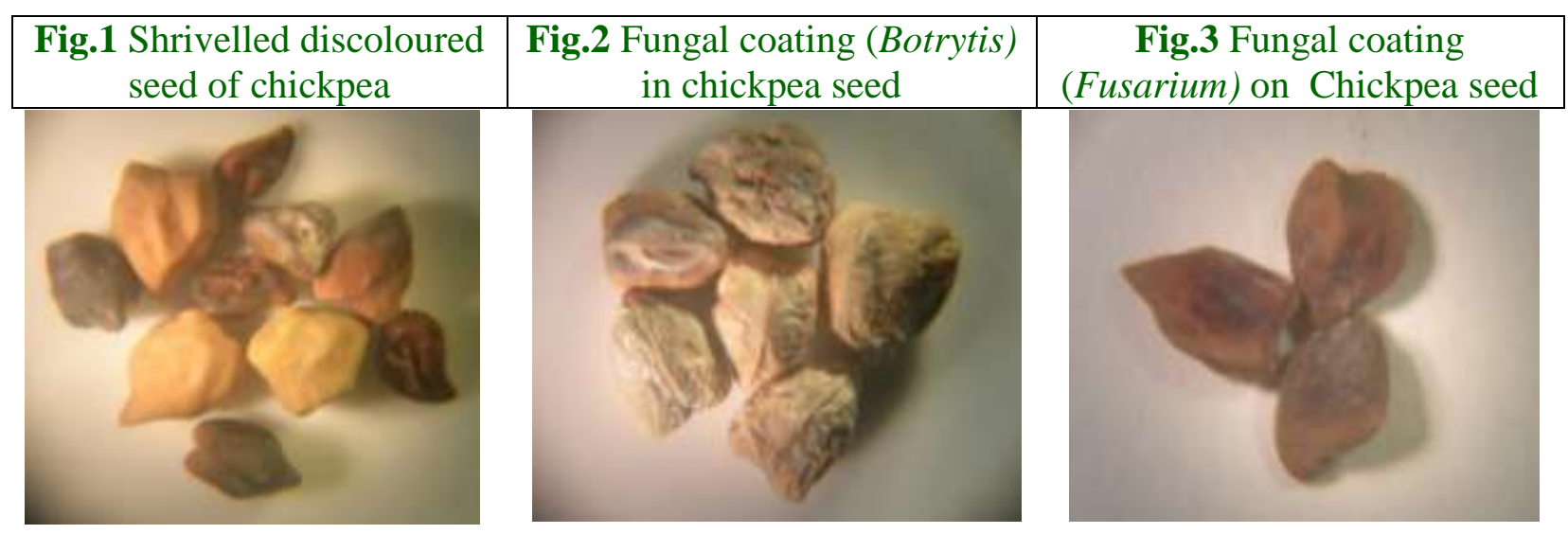

Fig.4 Effect of varieties on diversity of mycoflora and its impact on infection and germination in Sub-tropical India

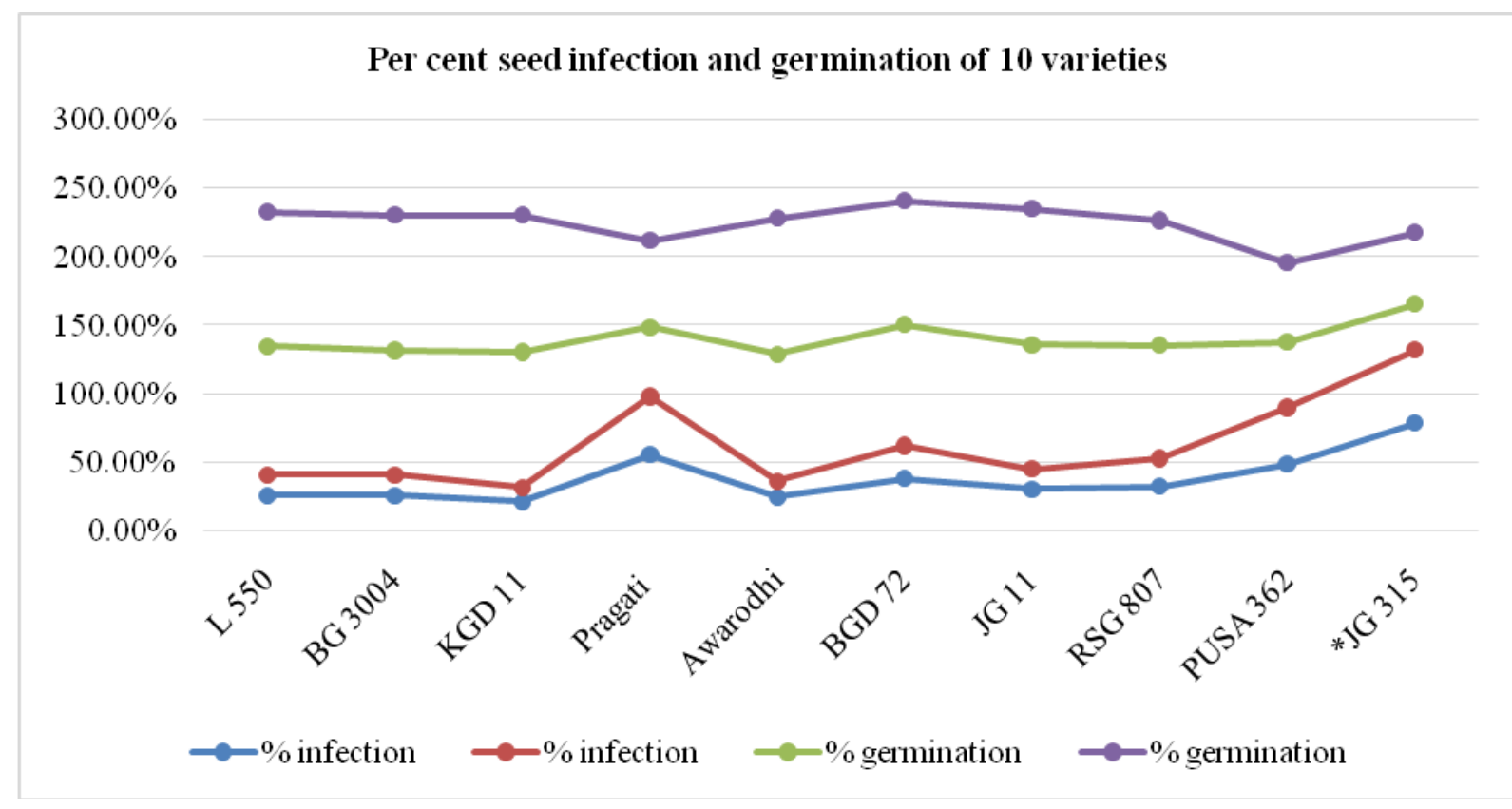

These species have been reported to reduce the germination of seed and damage the seeds in storage (Christensen, 1973). Jovicevic (1980) reported that the filter paper method was most practical method for routine analysis of seed health. Khan et al., (1988) found blotter and agar plate methods were more suitable for detection of Fusarium spp., and Chaetomium globosum from rice seed. Such similar results were observed by Dawar and Ghaffar (1991). It was also observed that surface sterilization of seed reduced the infection of $A$. flavus and $A$ niger and increased the incidence of pathogenic fungi. Such similar report has been made by Dawar\&Ghaffar (1991) on sunflower and Tariq et al., (2005) on soybean seed. Carranza (1965) observed that chickpea wilt which is caused by Fusarium spp., occur in the field of chickpea produced root rot and wilt disease. $A$. flavus mycotoxins producing fungi can cause severe damage to the liver, kidneys and 
nervous system of man even in low dosages (Rodricks, 1976). There is therefore need for reducing the pathogenic fungi by treatment of seed for obtaining the good quality of seed and also reduce the mould fungi and mycotoxin production by improving the storage conditions.

\section{References}

Agarwal, T., Malhotra, A., Trivedi, P. C. and Biyani, M. (2011). Bio control potential of Gliocladium virens against fungal pathogens isolated from chickpea, lentil and black gram seeds. Journal of Agril. Tech., 7: 1833-1839.

Bissett, H. L. (1991). Illustrated Genera of Imperfect Fungi. 3rd ed., Burgess Publ. Co. Minneapolis, Minnesota, 241 pp.

Carranza, J. M. (1965). Wilt of chickpea (Cicer arietinum) caused by Botrytis cinerea (in Spanish) Revista de la Faculted de agronoma, Universidad nacional de la Plata, 41: 135-138.

Christensen, C. M. (1973). Loss of viability in storage microflora. Seed Sci. \& Technol., 1: 547-562.

Dawar, S. and A. Ghaffar. (1991). Detection of the seed borne mycoflora of sunflower. Pak. J. Bot., 23(2): 173178.

Domsch, K. H; Gams, H.W. and Anderson, T. H. (1993). Compendium of Soil Fungi.Vol. I. Academic. Press, New York, 1089 pp.

Dubey, S. C., Singh, B. and Bahadur, P. (2007). 'Diseases of pulse crops and their ecofriendly management'. In: Ecofriendly Management of Plant Diseases. (Eds.). Ahamad, S. and Narain, U. Delhi: Daya Publishing House, pp. 16-44.

Hammil, M. J. (1970). An Annotated List of Seed-borne Diseases. Intl. Seed Test. Assoc., Zurich, Switzerland. 320 pp.
Hasan, M. M., Chowdhary, S. P., Alam, S., Hossain, B. and Alam, M. S. (2005). Antifungal effects of plant extracts on seed-borne fungi of wheat seed regarding seed germination, Seedling health and vigaur index. Pak. J. Biol. Sci., 8:1284-1289.

ISTA. (1996). International Rules of Seed Testing Assoc. In: Proc. Int. Seed Test. Assoc. pp. 19-41.

Jovicevic, B. (1980). Contribution to the knowledge of harmful mycoflora on seeds of wheat, maize and sunflower. Zastita Bilja, 31: 101-119.

Khan, S. A. J., Khanzada, A. K., Sultana, N. and Aslam, M.. (1988). Evaluation of seed health testing techniques for assessment of seed-borne mycoflora of rice. Pak. J. Agric. Res., 9: 502-505.

Kochhar, S.L. (2009). 'Economic Botany in the Tropics.' MacMillan India Ltd., Daryaganj, New Delhi. pp. 658.

Mukherjee, P. S., Nandi, S. K and Nandi, B. D. (1992). Changes in groundnut seeds in storage. J. of Mycopath. Res., 30(2): 113-119.

Neergard, Paul (1977): Seed pathology John Villy and sons, N.Y. I

Nene, Y. L., Sheila, V. K. and Sharma, S. B. (1996). 'A world list of chickpea and pigeonpea pathogens'. 5th Edition, ICRISAT, Patancheru, India. pp. 27.

Nirenberg, H. (1976). Untersuchungenuber die morphologische und Differenzierung in der Fusarium SektionLiseola.

Pereyra, G. M. L., Pereyra, C. M., Ramírez, M. L., Rosa, C. A. R., Dalcero, A. M and Cavaglieri, L. R. (2008). Determination of mycobiota and mycotoxins in pig feed in central Argentina. Letters in Appl. Microbiol., 46: 555-561.

Rasheed, S; Dawar, A; Ghaffar, S. and Shaukat, S. S. (2004). Seed borne mycoflora of groundnut. Pak. J. Bot. 36(1): 199-202. 
Rodricks, J. V. (1976). Mycotoxins and other fungal related food problems. Advances in Chemistry series 149. American Chemicals Society, Washington.

Singh, G. and Sharma, Y. R. (2005). 'Diseases of chickpea and their management.' In: Diseases of field crops and their management. (Ed.). Thind, T.S. Delhi:
Daya Publishing House, pp. 155-177.

Sutton, J. W. (1980). Genera of Hyphomycetes. The University of Alberta Press, 386 pp.

Tariq, M., Dawar, S., Abid, M. and Shaukat, S. S. (2005). Seed-borne mycoflora of soyabean. Int J. Biol. Biotech., 2(3): 711-7113.

\section{How to cite this article:}

Ankita Tripathi, Alok K. Srivastava, Alvina Farooqui, Ajita Singh, Dinesh Singh and Vainkteshvar K. Tripathi. 2019. Diversity of Seed-Borne Mycoflora in Relation to Different Chickpea Varieties in Uttar Pradesh. Int.J.Curr.Microbiol.App.Sci. 8(10): 2254-2263. doi: https://doi.org/10.20546/ijcmas.2019.810.261 